\title{
SYSTEMATIZATION OF TAX STRATEGIES FOR SHADOW ECONOMY PREVENTION UNDER CONDITIONS OF GLOBALIZATION
}

\author{
Eduard Romanyuta \\ Department of international economic \\ Ternopil National Economic University \\ 11 Lvivska str., Ternopil, Ukraine, 46000 \\ eduard.romanyuta@gmail.com
}

\begin{abstract}
The article studies main theoretical and practical aspects of the shadow economy functioning in the national and international environment. Levels of economic processes shadowing in European Union countries were grounded. A shadow sector volume in developed countries of the world was studied, and the international practice of economy de-shadowing was systematized. In the process of the study the essential attention was paid to fiscal instruments of shadow schemes prevention. Tax strategies of a fight against factors and motives that generate and intensify the shadow economy level in Ukraine were generalized on this base. It was proved, that there is practically no distinct panacea for the Ukrainian economy in the context of its de-shadowing. But the state is completely able to diminish shadow schemes diffusion in the economy using tax mechanisms. According to the results of the study the offers as to the shadow economy prevention in Ukraine were formulated on the base of the international experience and tax instruments.

Keywords: international economy, fiscal policy, tax strategies, shadow economy, de-shadowing of economy, tax control, globalization of economic relations.
\end{abstract}

\section{Introduction}

The shadow economy in Ukraine is the one of main barriers of the country competitiveness increase, rise of social norms of population life and integration with EU. Shadow economy problem exists in each country of the world but in several countries its volumes don't influence the official economy, in other ones - the shadow activity volume, more than $30 \%$ of GDP indicates the functioning of the reproductive system of the shadow activity of the country. Ukraine belongs to the second category with the shadow economy volume within the diapason from 30 to $60 \%$ of GDP according to different calculations. The large scale of the shadow economy in Ukraine is a result of the spread of a criminal economic behavior, corruption in state organs, low culture of juridical and natural persons in the legal and tax sphere.

The shadow economy exists for a long time and essentially increases its scales in economic processes of XXI century. The one of main problem questions of the modern development of world countries is the national economy shadowing. During the period of independence the shadow economy level grew under the influence of economic and political transformations and reached such level that provokes negative changes in the environment of the Ukrainian population life and a threat for the whole legal economy of the state.

Thus, the problems of tax strategies formation for the shadow economy prevention in the global dimension is urgent and needs further scientific studies.

\section{Literature review}

In the Ukrainian and European practice main problems of the study and approaches to the shadow economy scales dimension were considered and grounded in the following scientific works [1-3].

World tendencies of the economy management and economic processes de-shadowing are shown in [4-6]. General features of the shadow economy development in Ukraine, socio-economic consequences and ways of the shadow economy overcoming were studied in the works [7-9].

Theoretical and institutional principles of the shadow economy were fully grounded in the work [10].

The tax instrument of the shadow economy prevention was studied in works by such scientists $[11,12]$. The fiscal paradigm of the improvement of tax regulation mechanisms, and their 
use in the economy illegalization is elucidated in the studies [13, 14]. Directions of the economy de-shadowing in Ukraine using tax instruments in the modern globalization environment were studied in the work [15].

But the absence of the complex of coordinated tax arrangements that would resist the shadow economy in Ukraine for today and globalization tendencies to the deepening of economic processes shadowing generates and conditions the need for further scientific studies in this context.

\section{Aim and tasks of the research}

The aim of the article is in the substantiation and scientific enrichment of the following aspects:

- revelation of features of the shadow economy functioning in European Union countries and several developed countries of the world;

- systematization of fiscal theories, directed on the formation of tax strategies to prevent shadow schemes in the economy;

- formation of ways of the Ukrainian economy de-shadowing on the base of effective tax instruments and world experience.

\section{Materials and methods of the research}

The methodological base of the study is the systemic approach to the shadow economy phenomenon and also scientific achievements and works of foreign and native scientists in the sphere of the theory and practice of economic processes. At realizing this scientific study, general scientific and special methods of processes and phenomena monitoring were used: the method of social observation; statistical method; method of comparative analysis and synthesis; method of scientific prognostication and so on.

The informational base of the study were legislative and normative acts on problems of legalization and de-shadowing of the shadow economy; analytical and statistical-report materials of Ukrainian and world fiscal organs; materials of monographs, periodical editions of native and international organizations, internet-resources that contain information about the tax component of the shadow economy prevention.

\section{Results}

\section{1. Pragmatism of the shadow economy functioning in the international plane}

The process of world integration of shadow economical and social processes, masking of profits from taxation and their use for personal needs satisfaction negatively influence an economic crisis intensification, corruption and currency machinations rise. Economic processes in the shadow economy take place beyond the law influence area that complicates an activity of world economic communities and harmonious development of the society in whole.

Statistical data of shadow economy volumes of 28 EU countries during 2007-2016 years (in \% of GDP) are presented in Table 1. Having considered results of the mean shadow economy of 28 EU countries, it may be noted that the shadow economy in 2007 year was $21,1 \%$ (of the official GDP), and decreased to $19,6 \%$ in 2009 year and increased to $20,1 \%$ in 2010 year and then decreased again to $18,3 \%$ in 2016. Observing increases and decreases in 2016, the shadow economy development in separate countries remains unstable [1].

It must be also noted, that in the overwhelming majority of countries (21 of 28) the shadow economy level decreases and in other 6 ones - increases, and in 1 - remains the same. 21 EU countries with the decreasing shadow economy level are: Bulgaria, Croatia, Check Republic, Denmark, Estonia, Finland, Greece, Ireland, Italy, Latvia, Lithuania, Netherland, Poland, Portugal, Romania, Slovenia, Cyprus, Spain, Slovakia, Sweden and United Kingdom, whereas the shadow economy grows in Austria, Belgium, France, Hungry, Luxemburg and Malta, and in Germany the shadow economy level remains stable. The most rapid growth took place in France from 10,8 \% of the official GDP (2015) to $12,3 \%$ in 2016; and the strongest decrease was in Lithuania from $27,1 \%$ (2015) to $25,8 \%$ in 2016 [1]. 
Table 1

The volume of shadow economy of 28 EU countries during 2003-2015 years (in \% of GDP)

\begin{tabular}{|c|c|c|c|c|c|c|c|c|c|c|}
\hline Country/Year & 2007 & 2008 & 2009 & 2010 & 2011 & 2012 & 2013 & 2014 & 2015 & 2016 \\
\hline Austria & 9,7 & 9,4 & 8,1 & 8,5 & 8,2 & 7,9 & 7,6 & 7,5 & 7,8 & 8,2 \\
\hline Belgium & 19,2 & 18,3 & 17,5 & 17,8 & 17,4 & 17,1 & 16,8 & 16,4 & 16,1 & 16,2 \\
\hline Bulgaria & 34,0 & 32,7 & 32,1 & 32,5 & 32,6 & 32,3 & 31,9 & 31,2 & 31,0 & 30,6 \\
\hline Croatia & 31,2 & 30,4 & 29,6 & 30,1 & 29,8 & 29,5 & 29,0 & 28,4 & 28,0 & 27,7 \\
\hline Czechia & 18,1 & 17,0 & 16,6 & 16,9 & 16,7 & 16,4 & 16,0 & 15,5 & 15,3 & 15,1 \\
\hline Denmark & 15,4 & 14,8 & 13,9 & 14,3 & 14,0 & 13,8 & 13,4 & 13,0 & 12,8 & 12,0 \\
\hline Estonia & 29,6 & 29,5 & 29,0 & 29,6 & 29,3 & 28,6 & 28,2 & 27,6 & 27,1 & 26,2 \\
\hline Finland & 15,3 & 14,5 & 13,8 & 14,2 & 14,0 & 13,7 & 13,3 & 13,0 & 12,9 & 12,4 \\
\hline France & 12,4 & 11,8 & 11,1 & 11,6 & 11,3 & 11,0 & 10,8 & 9,9 & 10,8 & 12,3 \\
\hline Germany & 15,0 & 14,7 & 14,2 & 14,6 & 13,9 & 13,2 & 12,9 & 12,4 & 12,2 & 12,2 \\
\hline Greece & 26,2 & 25,1 & 24,3 & 25,0 & 25,4 & 24,3 & 24,0 & 23,6 & 23,3 & 22,4 \\
\hline Hungry & 24,4 & 23,7 & 23,0 & 23,5 & 23,3 & 22,8 & 22,5 & 22,1 & 21,6 & 21,9 \\
\hline Ireland & 13,4 & 12,7 & 12,2 & 13,1 & 13,0 & 12,8 & 12,7 & 12,2 & 11,8 & 11,3 \\
\hline Italy & 23,2 & 22,3 & 21,4 & 22,0 & 21,8 & 21,2 & 21,6 & 21,1 & 20,8 & 20,6 \\
\hline Latvia & 29,0 & 27,5 & 26,5 & 27,1 & 27,3 & 26,5 & 26,1 & 25,5 & 24,7 & 23,6 \\
\hline Lithuania & 30,6 & 29,7 & 29,1 & 29,6 & 29,7 & 29,0 & 28,5 & 28,0 & 27,1 & 25,8 \\
\hline Luxemburg & 10,0 & 9,4 & 8,5 & 8,8 & 8,4 & 8,2 & 8,2 & 8,0 & 8,1 & 8,3 \\
\hline Malta & 27,2 & 26,4 & 25,8 & 25,9 & 26,0 & 25,8 & 25,3 & 24,3 & 24,0 & 24,3 \\
\hline Netherland & 10,9 & 10,1 & 9,6 & 10,2 & 10,0 & 9,8 & 9,5 & 9,1 & 9,2 & 9,0 \\
\hline Poland & 26,8 & 26,0 & 25,3 & 25,9 & 25,4 & 25,0 & 24,4 & 23,8 & 23,5 & 23,3 \\
\hline Portugal & 20,1 & 19,2 & 18,7 & 19,5 & 19,2 & 19,4 & 19,4 & 19,0 & 18,7 & 17,6 \\
\hline Romania & 31,4 & 30,2 & 29,4 & 29,4 & 29,8 & 29,6 & 29,1 & 28,4 & 28,1 & 28,0 \\
\hline Slovenia & 25,8 & 24,7 & 24,0 & 24,6 & 24,3 & 24,1 & 23,6 & 23,1 & 23,5 & 23,3 \\
\hline Cyprus & 27,9 & 26,5 & 26,0 & 26,5 & 26,2 & 26,0 & 25,6 & 25,2 & 25,7 & 24,8 \\
\hline Spain & 20,2 & 19,3 & 18,4 & 19,5 & 19,4 & 19,2 & 19,2 & 18,6 & 18,5 & 18,2 \\
\hline Slovakia & 17,3 & 16,8 & 16,0 & 16,8 & 16,4 & 16,0 & 15,5 & 15,0 & 14,6 & 14,1 \\
\hline Sweden & 16,2 & 15,6 & 14,9 & 15,4 & 15,0 & 14,7 & 14,3 & 13,9 & 13,6 & 13,2 \\
\hline United Kingdom & 11,1 & 10,6 & 10,1 & 10,9 & 10,7 & 10,5 & 10,1 & 9,7 & 9,6 & 9,4 \\
\hline $\begin{array}{c}28 \mathrm{EU} \\
\text { countries/mean } \\
\text { (unweighted) }\end{array}$ & 21,1 & 20,3 & 19,6 & 20,1 & 19,9 & 19,6 & 19,3 & 18,8 & 18,6 & 18,3 \\
\hline
\end{tabular}

Source: composed on the base of $[1,4]$

If consider the shadow economy development of highly developed non-European countries of OECD in Australia, Canada, Japan, New Zealand and USA, we find such movement with time (Table 2). 
Table 2

The shadow economy level of several highly developed world countries (in \% of GDP)

\begin{tabular}{ccccccccccc}
\hline Country/Year & $\mathbf{2 0 0 7}$ & $\mathbf{2 0 0 8}$ & $\mathbf{2 0 0 9}$ & $\mathbf{2 0 1 0}$ & $\mathbf{2 0 1 1}$ & $\mathbf{2 0 1 2}$ & $\mathbf{2 0 1 3}$ & $\mathbf{2 0 1 4}$ & $\mathbf{2 0 1 5}$ & $\mathbf{2 0 1 6}$ \\
\hline Australia & 11,4 & 11,7 & 10,6 & 10,9 & 10,3 & 10,1 & 9,8 & 9,4 & 10,2 & 10,3 \\
Canada & 13,2 & 12,6 & 12,0 & 12,6 & 12,2 & 11,9 & 11,5 & 10,8 & 10,4 & 10,3 \\
Japan & 9,4 & 9,0 & 8,8 & 9,5 & 9,2 & 9,0 & 8,8 & 8,1 & 8,2 & 8,4 \\
New Zealand & 10,4 & 9,8 & 9,4 & 9,9 & 9,6 & 9,3 & 8,8 & 8,0 & 7,8 & 8,0 \\
USA & 7,5 & 7,2 & 7,0 & 7,6 & 7,2 & 7,0 & 7,0 & 6,6 & 6,3 & 5,9 \\
$\begin{array}{c}\text { Other OECD } \\
\text { countries/unweighted }\end{array}$ & 10,4 & 10,1 & 9,6 & 10,1 & 9,7 & 9,5 & 9,2 & 8,6 & 8,6 & 8,6
\end{tabular}

Source: composed on the base of $[1,4]$

In 2007 data of aforesaid countries had the shadow economy index - 10,4\%, in 2009 this index was only 9,6\%. In 2010 the shadow economy grew to $10,1 \%$, then decreased again to 8,6\% of GDP in 2014. In 2016 the shadow economy volume deceased in Canada and USA and increased in Australia, Japan and New Zealand from 10,2 \% (in 2015) to 10,3 \% in 2016, from 8,2 \% (in 2015) to $8,4 \%$ (in 2016) and from 7,8 \% (in 2015) to 8,0\% in 2016, respectively. In average in 2016 the shadow economy level in these 5 countries remained stable at the value $8,6 \%$

Alongside with it, it is worth noting that the shadow economy prevention in the international plane is characterized by the following aspects:

- The general behavior Code that includes multisectoral information exchange and monitoring of actions in the sphere of a fight against the shadow economy in EU countries was edited in Austria.

- A fight against the shadow economy in the Check Republic is realized using an observation of money laundering operations by Financial Analytical Unit (FAU) of the Financial Ministry [2].

- The role of special services in the control of the shadow economy spread in the country was intensified in the USA. Officials of security services such as FBI and CIA most often work in American concerns and corporations, in such a way controlling their activity.

- The main task of all organizations is to elaborate general principles of de-shadowing of a "shadow" activity at the national level and to spread effective ways of the "shadow" activity level shortening in each country of the world [3].

On the fiscal side, the shadow economy activity in a country is an illegal process, connected with the fact that financial results of enterprises in the shadow sphere are not registered at the state level, so are not taxed. The shadow economy prevention must be realized by two main directions, connected with the change of the proportional volume of the shadow and legal economy: decrease of the shadow economy level and increase of the legal one.

\section{2. Tax mechanisms of shadow phenomena prevention in economy}

\section{2. 1. The study of tax strategies of the shadow economy prevention}

The essential volume of the national economy shadow sector leads to the stop of the economic development and a threat to the economic safety of several economic sectors and country in whole. A neglect of the shadow economy weight leads to an unreal assessment of development directions, to short-term and long-term strategic solutions at the state level. It causes the need to decrease a negative effect of shadow economy factors.

It must be noted that when the legal economic system is not able to create all necessary conditions for an activity of economic subjects, it is a push for the shadow sector development in the economy. Until economic subjects receive all necessary conditions for their activity in the legal part of the economy, the entrepreneurial sector stays "in shadow". So, a state must search for a social compromise and at the same time to create conditions for the effective activity in the legal economic sector [11]. 
On the fiscal side, the shadow economy activity in a country is an illegal process, connected with the fact that financial results of enterprises in the shadow sphere are not registered at the state level, so are not taxed. The shadow economy prevention must be realized by two main directions, connected with the change of the proportional volume of the shadow and legal economy. The shadow economy level decrease causes the need to create the state strategy of regulation and influence on shadow processes that take place within a state.

So, we may consider strategies of the state influence on the shadow sector, taking into account advantages and disadvantages of each state strategy of the shadow economy prevention (Table 3).

\section{Table 3}

Agglomeration of tax strategies of the shadow economy state prevention

\begin{tabular}{|c|c|c|c|c|}
\hline & Conservative & Liberal & Radical & Anti-corruption \\
\hline Is directed on & Fight against corruption & $\begin{array}{l}\text { Control of branches that } \\
\text { cause the most material } \\
\text { loss to a state }\end{array}$ & $\begin{array}{l}\text { Complete elimination of } \\
\text { all forms of the shadow } \\
\text { economy }\end{array}$ & $\begin{array}{c}\text { Fight } \\
\text { against corruption }\end{array}$ \\
\hline $\begin{array}{l}\text { Acceptable } \\
\text { (allowable) share } \\
\text { of the shadow } \\
\text { economy }\end{array}$ & $\begin{array}{l}\text { This strategy find pos- } \\
\text { sible the shadow econo- } \\
\text { my existence excluding } \\
\text { a criminal component }\end{array}$ & $\begin{array}{l}10-20 \% \text { of GDP } \\
\text { (in branches, not connected } \\
\text { with national safety) }\end{array}$ & $\begin{array}{c}\text { This strategy presup- } \\
\text { poses the complete } \\
\text { absence of any shadow } \\
\text { economy manifestations }\end{array}$ & $\begin{array}{l}\text { Is directed only on } \\
\text { a fight against corruption }\end{array}$ \\
\hline $\begin{array}{l}\text { Instruments of } \\
\text { action }\end{array}$ & $\begin{array}{l}\text { Mainly rigid } \\
\text { force methods }\end{array}$ & $\begin{array}{c}\text { Preventive arrangements: } \\
\text { control intensification; } \\
\text { optimization of taxation process }\end{array}$ & $\begin{array}{c}\text { All existent and } \\
\text { accessible state levers } \\
\text { of influence }\end{array}$ & $\begin{array}{l}\text { Rigid control and creation } \\
\text { of the national program of } \\
\text { fight against corruption }\end{array}$ \\
\hline $\begin{array}{c}\text { Main } \\
\text { disadvantages }\end{array}$ & $\begin{array}{l}\text { Doesn't touch the rest } \\
\text { of branches of shadow } \\
\text { activity }\end{array}$ & $\begin{array}{l}\text { Continuous modernization of } \\
\text { the model is necessary }\end{array}$ & $\begin{array}{l}\text { Very wide } \\
\text { target spectrum }\end{array}$ & Difficultness of execution \\
\hline Main advantages & $\begin{array}{c}\text { Adjusted mechanism of } \\
\text { prevention }\end{array}$ & $\begin{array}{c}\text { Possible effect of multiplier and } \\
\text { favorable influence on } \\
\text { other social life spheres }\end{array}$ & $\begin{array}{l}\text { Directionality on elim- } \\
\text { ination of all shadow } \\
\text { economy manifestations }\end{array}$ & $\begin{array}{l}\text { Will create a series of } \\
\text { positive initiatives for } \\
\text { the industrial development } \\
\text { and investment growth }\end{array}$ \\
\hline $\begin{array}{l}\text { Possibility of } \\
\text { adaptation to } \\
\text { native realia }\end{array}$ & $\begin{array}{l}\text { The simplest strategy of } \\
\text { anti-shadow policy }\end{array}$ & $\begin{array}{c}\text { The most favorable at } \\
\text { the given stage of the state } \\
\text { economy development }\end{array}$ & $\begin{array}{l}\text { Unavailability of } \\
\text { the native economy and } \\
\text { society for this strategy }\end{array}$ & $\begin{array}{l}\text { Is already introduced as } \\
\text { a national program }\end{array}$ \\
\hline
\end{tabular}

Source: composed on the base of $[5,7]$

A fight against the shadow economy criminal sector provides the use of the conservative strategy and the radical one is aimed at the vast liquidation of the shadow economy. The need to use the liberal strategy of the shadow economy state regulation is directed on using arrangements as to corruption prevention, complete control of credit and money chains, directed on the vast shortening of the shadow economy level [7].

The large-scale type of the shadow economy became widespread in Ukraine at the world economic and financial crisis. According to assessments of ministries, offices and separate experts, the shadow economy level in Ukraine varies from 38 to $60 \%$ of GDP and is a real danger for the society and national economy. It is possible to establish the real finish of the shadow economy activity on the territory of Ukraine [6].

The main shadow activity types in Ukraine include: illegal ways of profits minimization by enterprises; illegal outflow of the capital abroad; financial machinations; creation of the paper tax credit.

The dynamics of the integral index of the shadow economy of Ukraine during 2010-2016 is presented on Fig. 1.

Having analyzed the integral index of the shadow economy of Ukraine, we can make a conclusion about the large-scale spread of the shadow economic activity in Ukraine and unstable growth and fall of the shadow economy level during 2010-2016. 


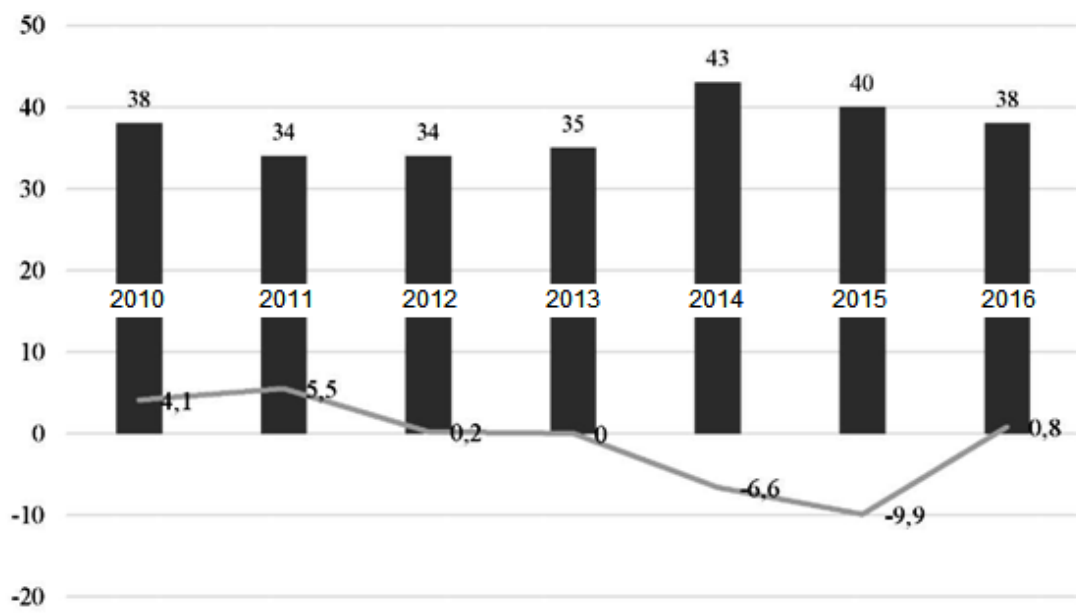

Fig. 1. Integral index of the shadow economy level in Ukraine (in \% of GDP volume) and speeds of increase/decrease of the real GDP level (in \% to the correspondent period of the previous year)

Source: composed on the base of $[8,16]$

Under modern conditions of economic changes and political instability, the long-term budgetary policy cannot function effectively. Every year the Ukrainian budget is made by data of the national economy, namely, due to the analysis of macroeconomic indices. The one of most shaded components of budgetary incomes is incomes from capital operations. The growth of the shadow economy level in Ukraine favors the socio-economic development braking, as a result of which the shortening of state programs financing takes place. So, the income of assets from legalization is an urgent problem for Ukraine [10].

So, the problem of the budget formation must be realized not by the increase of the tax load on honest tax payers, but by activation of reserves, present in the economy and also at the expanse of the shadow sphere.

\section{2. 2. Tax aspects of the Ukrainian economy de-shading taking into account the foreign experience}

The essential shadow economy sector in Ukraine, comparing with the mean index in Europe $(18,3 \%)$, demonstrate the imperfect activity of state authorities in the economy de-shading sphere.

The activity of the State fiscal service of Ukraine also contains several shortcomings. The main part of the shadow capital is in the taxation sector. It may be seen from the analysis of indices, used at the calculation of the shadow economy level. Schemes for receiving the shadow capital at the expanse of illegal operations with GDP compensation are created.

The real necessity of crucial changes in approaches to interrelations between subjects of taxation and the State fiscal service becomes imminent in Ukraine. As a result the increase of the level of free will in taxation takes place.

The increase of the taxation culture level in tax payers is first of all favored by the spread of a tax consulting in the taxation sphere. A tax consulting in Ukraine must be formed based on the distinctly determined place and role of tax consultants in three-side relations between tax payers, fiscal organs and tax consultants, interpreted not only by auditors, jurists and accountants, but also professional associations. It will favor the construction of the qualitatively new level of interactions between subjects of tax jural relationship and SFS in the sphere of taxation, aimed at the conscious understanding of incomes and profits declaration and, as a result, on the development of not only fiscal effects but also social ones [13].

So, the State fiscal service of Ukraine needs the improvement and elaboration of effective ways of the shadow economy prevention under modern conditions.

The shadow economy level in Ukraine remains high and unstable. As a result of economic and political changes in the state new shade and corruption spheres in state organs appear. In separate sectors of the national economy the shadow activity is not subjected to legislative norms, for 
example: economic cyber-criminality, contradictory and imperfect regulatory and legal framework that contains obstacles at making decisions. In general, the activity of Verhovna Rada of Ukraine and Cabinet of Ministries of Ukraine in the shadow economy sphere doesn't correspond to modern needs of the market economy [15].

The insufficiently wide reference of multifunctional organs prevents their effective control and counteraction to shadow processes. Also the partial combination of potentials of these organs on shadow processes and interconnections and cooperation in the shadow sphere need essential material and human resources. So, it is necessary to create the united specialized organ for the economy shading prevention that would help the effectiveness of the economy de-shadowing administration in Ukraine.

The following offers must be used for the Ukrainian economy de-shading [9, 14]:

1. To raise the market regulation of the economy and to realize the anti-corruption reform, creating new information system in state organs that would favor the elimination of corruption.

2. To aim the tax reform at guaranteeing taxes administration by tax amnesty realization, introduction of tax administration e-systems, tax load decrease.

3. To reform the bank system that would make possible the growth of non-cash payment volumes and control of income sources.

4. It is necessary to increase the administrative responsibility for inofficial labor relations and defaulting from insurance and tax payments.

The one of most prospective directions of the Ukrainian economy de-shading is the favorable investment climate formation, tax pressure shortening in the entrepreneurial activity sphere, legislative support of labor relations and proprietary rights.

Alongside with improvements in the socio-economic development, de-shading of economic relations and further solution of fiscal problems in Ukraine at the tax policy formation, the one of EU and its countries-members must be taken into account more and more (first of all, to bring the native tax legislation in correspondence with principles of EU directives as to taxation, not mentioned in the Association) [12].

Tax methods of the shadow economy prevention are complicated and multivector phenomenon, so the active counteraction to the economy shading must be realized due to the interaction between legislative and executive organs, state services and society under the influence of the Ukrainian valid legislation.

\section{Discussion of the results}

It is important to note that the execution of offers, outlined as a result of this study will be effective only under conditions of the qualitative revelation of the localized shadow activity in entrepreneurial sectors. The discussion moment of the work is in the thought that in the process of a fight and prevention of the shadow economy one must go beyond real indices and international experience that indicates that it is unreal to eliminate the shadow economy under today economic, political and social conditions completely. It is useful for the Ukrainian system to orient on the decrease of the shadow economy level in highly developed countries of the world. As our research proved it, it is real only at realizing the effective tax and economic policy in the aspect of the shadow economy prevention.

The practical importance of the received results may be reduced to the fact that scientific hypotheses and generalizations may be used in the activity of state authorities (including SFS of Ukraine) in the context of revelation of factors and schemes of defaulting from taxation and also in the improvement of the shadow economy prevention policy in Ukraine.

\section{Conclusions}

Thus, the following conclusions may be formulated as a result of this study:

1. As a result of the monitoring of shadow economy functioning tendencies in EU countries and several developed countries of the world it was proved, that the tax policy in the international global environment has the essential influence on the shadow economy volume. The analysis of the shadow economy level in EU countries and several developed countries of the world testified 
evident tendencies to its decrease and essential differences and much less volumes, comparing with Ukrainian indices.

2. To improve the shadow economy prevention in Ukraine the author paid the special attention to the systematization of tax strategies, as a result, it was established that it is expedient to use the conservative strategy in a fight against the criminal sector of the shadow economy, and the radical strategy must be aimed at the vast elimination of the shadow economy. The need in the state regulation liberal strategy is directed on arrangements as to the corruption prevention, full control of credit and money chains, directed on the vast shortening of the shadow economy level.

3. The study demonstrated that the formation of ways of the Ukrainian economy de-shading must be based on the effective tax policy realization taking into account achievements of world countries in this aspect. It was established, that to decrease the shadow economy level in Ukraine it is necessary to realize the following tasks in the tax sphere: improvement of the fiscal policy to shorten the tax load on subjects of the entrepreneurial activity; intensification of the tax control and observation of the credit and financial sector of the national economy; fiscal controls of external economic operations; control of systemic character, timeliness and completeness of the salary indexation by taxation subjects; establishment of tax abatements for assets investments in the innovation sphere; intensification of the tax control of risk tax payers; fight against corruption and increase of citizens; trust to state control organs in the taxation sphere.

\section{References}

[1] Schneider, F. (2015). Size and Development of the Shadow Economy of 31 European and 5 other OECD Countries from 2003 to 2015: Different Developments. Available at: http://www.econ.jku.at/members/ Schneider/files/publications/2015/ShadEcEurope31pdf

[2] Riznyk, N. S. (2011). Upravlinnia detinizacieiu ekonomiky: dosvid YeS. Available at: http:// nbuv.gov.ua/UJRN/ecnem_2011_8_30

[3] Slemrod, J. (2014). Cheating Ourselves: The Economics of Tax Evasion. The Journal of Economic Perspectives, 21(1), 28.

[4] Mizhnarodnii dosvid zapobigannia ta protydii korupcii (2016). Available at: http://stepup.press/ analytics/item/412-mijnarodnij-dosvid-shodo-zapobigannja-ta-protidiji-korypcii

[5] Global Shadow Banking Monitoring Report (2015). Available at: http://www.fsb.org/wp-content/uploads/global-shadow-banking-monitoring-report-2015.pdf

[6] Bleyds, D. (1982). Tenevaya ekonomyka i natsyonalnye scheta. Ekonomycheskyy obzor stran OESR, 123.

[7] Rybchak, O. S. (2012). Tinova ekonomika ta osoblivosti ii rozvitku v Ukraini, 21.

[8] Tendentsiyi tinovoyi ekonomiky v Ukrayini (2016). Ministerstvo ekonomichnoho rozvytku i torhivli Ukrayiny, 21.

[9] Baranov, S. O. (2015). Tinova ekonomika: sutnist, prychyny, sotsialno-ekonomichni naslidky ta shlyakhy podolannya v Ukrayini. Available at: http://nbuv.gov.ua/UJRN/Vnadu_2015_3_9

[10] Shaposhnykov, K. S. (2015). Instytutsionalni zasady funktsionuvannya pozalehalnoyi (tinovoyi) ekonomiky. Stratehiyi ekonomichnoho rozvytku: derzhava, rehion, pidpryyemstvo. Kherson: Vydavnychyy dim «Helvetyka», 2, 400.

[11] Varnalii, Z. S. (2009) Aktualni problemy zabezpechennia nacionalnoi ekonomichnoi bezpeky v Ukraini. Naukovii visnik Lvivskogo derzhavnogo universitetu vnutrishnsh sprav, 1. 1-18.

[12] Krisovatiy, A. I., Melnik, V. M., Koshchuk, T. V. (2016). Sutnist ta kontseptualni osnovi formuvannya podatkovoyi politiki v umovah evrointegratsiynih protsesiv. Ekonomika Ukrayini, 1, 3551.

[13] Tkachyk, F. P. (2015). Podatkove konsultuvannya. Navchalnyy posibnyk Ternopil: Vydavnychyy tsentr «Vektor», 250.

[14] Nikitishyn, A. O. (2016). Osnovni napryamy vdoskonalennya mekhanizmu podatkovoho rehulyuvannya. Available at: http://www.economy.nayka.com.ua/?op=1\&z=4789

[15] Dvorianinov, A. V. (2013). Napriamy detinizacii ekonomiky Ukrainy cherez zastosuvannia podatkovih mechanizmiv. Finansovyi prostir, 4 (12), 151-156.

[16] Dokhody byudzhetu Ukrayiny (2016). Available at: http://cost.ua/budget/revenue/ 